\title{
Adversity Quotient of Students of Early Childhood Education Program Who Experiencing Tsunami
}

\author{
Andi Agusniatih ${ }^{1}$ and Shofiyanti Nurzuama ${ }^{2}$ \\ ${ }^{1}$ Early Childhood Education Department, University of Tadulako, Palu, Indonesia, andiagusniatih@ gmail. com \\ ${ }^{2}$ Early Childhood Education Department, University of Tadulako, Palu, Indonesia, shofiyantinurzuama@ gmail. com
}

\begin{abstract}
Students of the early childhood education program are prepared to teach at kindergarten. However, some natural disasters might affect their psychology. This research aims to determine the description of adversity quotient of students at Early Childhood Education Program of FKIP Tadulako University force 2015 affected by natural disaster, tsunami. The type of research used in this study is qualitative descriptive. The subject of research involved amounted to two respondents of the 2015 study, experiencing a natural disaster on tsunami. The methods used are observation and in-depth interviews. The results showed that the adversity quotient experienced by both students were climbers. It is seen from the four aspects of adversity quotient, namely 1) Control (C); 2) Origin-Ownership (O2); 3) Reach (R); and 4) Endurance (E). They tend to demonstrate good control or self-control, as they are able to respond to tsunami events by conducting self-rescue measures appropriately. Origin-Ownership (O2) is aware of the difficulties come from self that make them pay attention to the condition around to be more cautious and disciplined at the time of Maghreb should have been in the house. In addition, reach is the difficulties that come to affect daily activities, but there is a passion and optimism in the future looking at, making them back struggling, steadfast and rigid to re-complete the remaining studies completing His proposal. Existence of this endurance, able to survive and strive to solve the difficulties that continue to occur, the result of still recovering from trauma, has not focus on the completion of the proposal until finally strengthen themselves by sharing stories and stories with lecturers and lecturers faculty to get positive reinforcement and best support in order to focus on the final goal of being a Bachelor of education.
\end{abstract}

Keywords: Adversity quotient, natural disasters, tsunami

\section{INTRODUCTION}

Every individual or student is in a difficult condition where they have to face various demands from within and increasingly heavier environments, so that they are prone to stressful conditions. Moreover, if the difficult condition experienced it was a tsunami incident in Palu City. The direct experience during the tsunami is certainly recorded clearly in memory and in poor memories and sadness when seeing the impact left so devastating. The amount of damage and death before the eyes. Trying to find help, but all are thinking about each other's interests. Appropriate and adequate Adversity quotient will help students in the face of various difficult conditions so it is not easy to stress in the face of various difficult conditions. If students have the ability to face various difficulties experienced, then the various difficulties that there is not easy to make him feel depressed (stressed).

For some people who have low AQ can cause despair, surrender and do not want to try again, but for some people who have a high AQ, failure is only a result that is less good and can be improved. Therefore, adversity quotient is considered a factor that can determine the attitude and ability of a person to encounter difficulties (Stoltz, 2000). Stoltz (2000) also added that adversity quotient is an ability to turn barriers into a successful opportunity to achieve goals. The intention of changing the obstacles here is how an individual manages, addresses and responds to problems when the problem arises, or in other words the ability that a person has to endure difficulties or Barriers and ability to overcome them.

According to the definition of the adversity quotient, researchers received information on two of the 2015 force guidance students who experienced a direct tsunami incident on September 28, 2018. The incident obviously gave a very traumatic experience that took a long time to return to Palu for about six months, to continue the process of mentoring and also to help with their self-recovery process.

It is expressed by Widyaningrum (2007), that fighting power plays a big role in affecting one's efforts in overcoming the difficulties experienced. Individuals who have strong Adversity Quotient will be able to overcome the difficulties faced by him. When students have the ability to face various difficulties experienced, 
the various difficulties that exist, certainly not easy to make him feel depressed (stressed), and increasingly form a tolerance to stress, because the individual is able to effectively and more precisely handling stress.

The same opinion of Riyanti in Maryanti (2005) that adversity is the ability to pass through challenging times, survive and thrive in difficult situations as well as ability to overcome difficulty changes. The level of adversity quotient of each person is certainly different. Seligman in Stoltz (2000) confirms that individuals who have low adversity quotient tend to respond to events or difficulties as something that is fixed and generalized to other areas of life, whereas those who has a high adversity quotient, assuming a difficult situation as something temporary and limited in nature. Seligman mentions the distinction as optimism and pessimism.

Meanwhile, Bhayu (2010) explains that "Adversity quotient is the ability to trimoingpandum or Qona'ah". That means in everything we face and accept, we have to be able to find the blessing in disguise. In any difficulty, there must be ease. Then Bhayu (2010) also mentions that "this personality powers as 'chewy power'. The term itself means flexibility. So, AQ is a special intelligence related to the flexibility of a person facing a problem of life. The more bending he was, the more capable he faced life". This indicates the tolerance of individuals in the face of the necessary problems is more flexible or loose than too depressed or disputed.

Based on several descriptions of $\mathrm{AQ}$ and the conditions experienced in both students of the 2015 class, can be categorized as an ability to change the obstacles or difficulties faced during the tsunami natural disaster, become an opportunity to face and make the right decision and according to existing conditions, called Adversity Quotient (AQ).

Stoltz (2000) mentions the four dimensions that compose a person's adversity quotient; the four dimensions are described as follows:

1. Self control (control). Individual ability in positively influencing a situation, as well as being able to control the response to the situation, with the initial understanding that anything in any situation an individual can do so this dimension has two phases i. e. the first, the extent to which one is able to positively influence a situation. Secondly, the extent to which one is able to control the response to a situation.

2. Origins and recognition (Origin and ownership). That is an individual's ability to place feelings of himself boldly endure the consequences of existing situations, thus creating a learning in making improvements to the problems that occur. This dimension measures the extent to which a person bears the consequences of the current situation, without compromising the cause.

3. Reach. Individual ability to reach and limit problems to avoid reaching other areas. This dimension sees the extent to which individuals let adversity reach other areas of work and individual living.

4. Endurance. That is the ability of individuals in the conception of difficulties, and the strength in facing difficulties by creating ideas in reducing the problem so that the hardness of the heart and courage in problem solving can be realized. This dimension seeks to see how long a person has been misconception this accident will take place.

The description of this level or AQ type, also described by Stoltz (2005) that every human being born has a "core thrust" that always encourages every human being to climb. This impulse moves the purpose of our lives forward, regardless of the purpose itself. This core thrust is instinctive and can not only be done by individuals but also groups. Further, Stoltz (2005) divides the humans into 3 types, as follows:

1. Those who quit (Quitters). People who have this type are the ones who avoid obligations and stop facing life's challenges. They stopped the climb in his life. This type of person is the one who leaves his core impulse also means leaving the opportunity offered in his life and often regrets later on. As a result they become cynical, deflation, frustrating and often spending time without use. In the workplace, they do not show the desire to go forward, quite satisfied with what is acceptable, their quality is substandard, and not creative. Whereas, in interpersonal relationships, although capable of comrades but their relationship is meaningless. In the face of difficulties, a quitter has no guts to overcome it. Level quitters that are the weakest person adversity quotient. When facing the various difficulties of his life they stopped and directly gave up they chose not to climb, they came out, backed up, and avoided the duties or duties of life. They don't take advantage of opportunities, potentials, and opportunities in life. Examples: An individual or a student who does not bequest only complains when overridden bad conditions such as suffering, poverty, and ignorance and so on.

2. Those who camped (Campers). In the beginning, people of this type had a strong determination to climb but in the middle of their journey stopped and had a break. In difficult situations, they quickly end his struggle and find a safe place and hide from adversity. Such a person is quickly bored despite trying to try. Therefore, in the lifestyle of this group is almost the same as people who type of quitters. Therefore they are often called the satisfier that is already quickly satisfied with suffice self and do not want to develop themselves. In the workplace, although they are actually able to be creative and can take risks, they usually refuse and seek safe only. Level of Campers, i. e. adversity quotient medium level. Initially they were enterprising, struggling to solve life challenges. But in the middle of the trip they stopped too. They have been saturated, bored, felt enough, ended the climb by finding a flat and comfortable place. Example: A student who thinks that success is an important one has gone up or graduated, even if it is just okay.

3. The climbers (Climbers). A climber is someone whose lifetime is devoted to climbing. He did so, because he was a thinker who always thought of possibilities. This type is actually living a complete life, because they understand the purpose of his life. Climbers are resilient, persistent, steadfast and not easy 
to despair. At work they love the challenge, can motivate themselves, want to learn for life and make continuous improvements and not be afraid of changes. The Climbers level is a true climber. Lifelong people devote themselves to the ascent of life. They understand and realize that success is not just the physical dimension of material, but the whole dimension: physical, moral, spiritual, and so on. They is able to exert powers face life.

Based on these descriptions, it is understandable for researchers to know the description and development of adversity quotient with the various aspects listed therein, from the control, origin-ownership, reach, and endurance aspects. In addition, the level or type of adversity quotient which more precisely depicts the personal of students who have experienced natural disasters tsunami.

\section{RESEARCH METHODOLOGY}

The type of research selected is qualitative descriptive. The research location is conducted in the classroom or the surrounding environment at the PG PAUD FKIP study Program of Tadulako University. The research time is conducted for four months, starting from January to April 2019. Researchers have been conducting data collection in the form of observations and more in-depth interviews with research respondents to understand and know the adversity quotient on both students of the PG PAUD Force 2015 study Program affected by natural disasters tsunami.

This analysis section discusses the adversity quotient of two respondents that have been selected. The respondent in this study was a student of Prodi PG PAUD Force 2015, the first students named "R" and "AN", the same age, that is 22 years. And A stays one with the residence of different origin: $\mathrm{R}$ is derived from Toli-Toli and A from Parigi Moutong.

\section{ANALYSIS OF RESEARCH}

Based on an overview of the research respondent's profile, researchers began research from the middle of January by conducting long-distance communications, such as calls, via SMS or WA, to explore the experiences and feelings of trauma they still so still not ready to go back to campus. In fact, co-generation and joint guidance of about 15 students, was completed this research in March 2019, two new respondents could be ready to return to Palu in March 2019. The following interview and overview of AQ students have been researched below.

\section{Overview of Adversity Quotient Respondents Research}

The adversity quotient overview experienced by research respondents has various factors affecting both physical and psychic conditions. The following explanations is outlined.

Table 1 Overview of Adversity Quotient Respondents Research on Control

\begin{tabular}{|c|c|c|}
\hline \multirow{2}{*}{$\begin{array}{c}\text { ADVERSITY } \\
\text { QUOTIENT ASPECT }\end{array}$} & \multicolumn{2}{|c|}{ INTERVIEW RESULTS } \\
\hline & RESPONDENTS "R" & RESPONDENTS "AN" \\
\hline $\begin{array}{l}\text { Control (Respond to } \\
\text { negative responses with } \\
\text { positive response) }\end{array}$ & $\begin{array}{l}\text { At the time of the incident, it is still confused as } \\
\text { to why someone had fallen in front of them, it } \\
\text { was only realized that it was the first } \\
\text { earthquake. Just tried to stand after the first } \\
\text { earthquake, because the position behind the } \\
\text { beach, some keep screaming: "There is water, } \\
\text { water rises, water rises... ". } \\
\text { Before looking, from a distance see there is a } \\
\text { tall building straight down. Then look towards } \\
\text { the beach, there is a rolling wave. Briefly } \\
\text { observed, immediately seeking a path for these } \\
\text { two children to be secured, because it is } \\
\text { impossible to run. In fact, the waves are closer } \\
\text { to that height. Then see there is a car parking, } \\
\text { can be opened, and then cried apostles a friend } \\
\text { who was dirty, silent motionless. He was close } \\
\text { to holding his second hand. Children are } \\
\text { immediately inserted into the car. } \\
\text { Trying to stay calm and rigid, because keep the } \\
\text { two children who are jaged to be added fear and } \\
\text { hysterical with a water tsunami that is } \\
\text { completely black dense, very dirty, and } \\
\text { completely submerged to under the chin. The } \\
\text { left hand keeps a broken car window with a } \\
\text { torn banner found around the car, while the } \\
\text { right hand holds the child's body so that the } \\
\text { position is always above the water surface. }\end{array}$ & $\begin{array}{l}\text { The reactions shown are different. It can only be } \\
\text { silent and the body feels stiff, very shock to see } \\
\text { seawater run, it feels very scared, but the legs } \\
\text { can not move. The body is like being stuck on } \\
\text { the ground, until finally his friend "R" pulls his } \\
\text { hand and wiggling his body that feels so heavy } \\
\text { to move. } \\
\text { After feeling the body was able to move, } \\
\text { although helpless, but he tried to strengthen } \\
\text { himself, because there are } 1 \text { children who also } \\
\text { feel afraid is in the palm of his hand. They tried } \\
\text { to run away, but felt it could not be faster than } \\
\text { water, and then saw there was a car that had } \\
\text { been abandoned by the owner. They got into the } \\
\text { car, faster the water burst towards the car where } \\
\text { they took refuge in it. } \\
\text { It feels like a choke and can no longer withstand } \\
\text { the cold and the body, hands, and legs, while } \\
\text { keeping the nearby child in order to position } \\
\text { above the water's surface. Between resisting the } \\
\text { cold and stiffness of the body, he heard his } \\
\text { friend entertain the two children who sounded } \\
\text { the teeth of the starred opposite and their bodies } \\
\text { shivering to withstand the cold taste, to read the } \\
\text { memorization of short letters that have been } \\
\text { mastered, to be distracted their attention to } \\
\text { memorization of his letter. }\end{array}$ \\
\hline
\end{tabular}


Table 2 Overview of Adversity Quotient Respondents Research on Origin-ownership, reach, endurance

\begin{tabular}{|c|c|c|}
\hline \multirow{2}{*}{$\begin{array}{c}\text { ADVERSITY } \\
\text { QUOTIENT ASPECT }\end{array}$} & \multicolumn{2}{|c|}{ INTERVIEW RESULTS } \\
\hline & RESPONDENTS "R" & RESPONDENTS "AN" \\
\hline $\begin{array}{l}\text { Origin-Ownership } \\
\text { (realizing trouble comes } \\
\text { from oneself) }\end{array}$ & $\begin{array}{l}\text { I am sad and feel guilty, because I want to } \\
\text { follow the wishes of the two children who have } \\
\text { been dititipi or married by their same mother, } \\
\text { when they are willing to get ahead of Maghrib } \\
\text { time, go about } 5 \mathrm{pm} \text {. } \\
\text { We moved the place from the Anjungan } \\
\text { Nusantara which has begun to be limited or } \\
\text { closed its location from the afternoon to prepare } \\
\text { the opening activities of the Nomoni Festival } \\
\text { later tonight. The last place that is visited is } \\
\text { around the fishing village. The two children are } \\
\text { still waiting to be able to climb the toy that runs } \\
\text { until the tsunami comes unexpectedly. }\end{array}$ & $\begin{array}{l}\text { The mistake we have done which is really } \\
\text { regretted is not to pay attention to the time to } \\
\text { play outside the house, let alone still be around } \\
\text { the beach or sea when before Maghrib. } \\
\text { We are less sensitive or sensitive when faced } \\
\text { with their hassling and immediately follow their } \\
\text { willingness, without thinking about the risks that } \\
\text { will occur. This makes us more cautious in } \\
\text { making more informed decisions, including } \\
\text { deciding on everything with a mature } \\
\text { consideration, as well as being more tailored to } \\
\text { existing situations and conditions. }\end{array}$ \\
\hline $\begin{array}{l}\text { Reach (difficulties that } \\
\text { come to affect daily } \\
\text { activities) }\end{array}$ & $\begin{array}{l}\text { Two months of the incident, still very traumatic } \\
\text { once. Not yet dare to go out of the house, love } \\
\text { to cry until it continues to be strengthened by } \\
\text { parents that all have already destined Allah to } \\
\text { me naturally. } \\
\text { Due to my condition that has not been stable } \\
\text { physically or mentally, can not directly join the } \\
\text { KKN with friends. When they were able to test } \\
\text { the thesis at the end of } 2018 \text {, I was still not } \\
\text { allowed to return to Palu and continue the } \\
\text { process of mentoring the proposal that has not } \\
\text { been progressing. After strengthening and rigid } \\
\text { when facing problems at home, the trust of the } \\
\text { parents became a way back knit dreams and the } \\
\text { mind of achieving the study that had been } \\
\text { delayed. }\end{array}$ & $\begin{array}{l}\text { My condition is very drop once. I still can not } \\
\text { talk much, still very frightened to imagine the } \\
\text { incident in front of the eyes. The body feels still } \\
\text { very helpless, limb once, it still takes a long } \\
\text { time to adapt to the water to dare out the house. } \\
\text { Parents do not allow back to Palu, although it } \\
\text { has been very much left over from other } \\
\text { mentoring friends who have partly been a } \\
\text { bachelor. It took time to establish strength and } \\
\text { stubbornness when understanding the test of } \\
\text { God's proof of affection and still always keep us } \\
\text { with his best care and protection. }\end{array}$ \\
\hline $\begin{array}{c}\text { Endurance } \\
\text { (Able to survive and } \\
\text { strive to solve } \\
\text { difficulties) }\end{array}$ & $\begin{array}{l}\text { The incident made me realize that I was able to } \\
\text { survive and was able to act quickly in } \\
\text { difficult,unexpected situations, plus there were } \\
\text { two children who had to be protected and } \\
\text { guarded, and could immediately save } \\
\text { themselves. } \\
\text { This makes me recover faster and start making } \\
\text { targets to be a bachelor in this year. Support } \\
\text { and the primary prayer of parents and family so } \\
\text { that I can endure and be able to overcome all } \\
\text { difficulties by continuing to maintain the same } \\
\text { good thought of God. Keep the spirit of living. } \\
\text { About life and death is only God who knows. } \\
\text { Hope to be turned off in good condition } \\
\text { (Husnul khotimah). Aamin yaa Rabb. }\end{array}$ & $\begin{array}{l}\text { First faced with the incident of the tsunami, I } \\
\text { was not able to refrain. If I am not with my } \\
\text { friend "R", I do not know my fate then, because } \\
\text { I can not act immediately or respond as } \\
\text { expected. } \\
\text { Due to my rather slow reaction and of course } \\
\text { making my friend into trouble dealing or finding } \\
\text { my way out, I got very hit and felt guilty. As if } \\
\text { forgetting there is God, a place of complaining } \\
\text { and asking for help. Feel yourself, when God is } \\
\text { always with me, keep and give the best path as } \\
\text { long as I have difficulties. It made me repent } \\
\text { immediately, again prayer to be a servant of God } \\
\text { who was always grateful. }\end{array}$ \\
\hline
\end{tabular}

Based on the interviews of the experiences they have traveled in the event of a tsunami happening before them, it is understandable that the natural disasters of the tsunami are very intimidating, when viewed through video views on YouTube or various media of other social things, certainly feel the same sadness and fear. While experiencing it yourself, if we are in a situation as we have seen through the impressions, certainly our condition is not necessarily better than those who have struggled and survived for a long time, and be patient with aid and assistance that takes a very long time.

According to the description and explanation of both students, it can be concluded that in general from the AQ aspect, both have experience that confirms their mental condition become stronger, resilient, and can survive again in the future. Of course, each person needs time to recover, but their struggle faces each difficulty without avoiding or closing themselves, making them 
recover faster and immediately seeking help from Guardian professors and thesis mentor lecturers to Help to solidify their goals, hopes, and ideals in order to become a scholar and boast of their parents.

\section{Overview of Levels or Adversities Quotient Type}

According to the explanation of the level or type of AQ above, can be seen from the description of four aspects of AQ, namely control, origin-ownership, reach, and endurance, then three types of AQ more precise to describe the second AQ students who have experienced Experience of devastating tsunami natural disasters is the type of Climbers. This type is a picture of the person who made it to the top of the climb, in this case can be considered able to overcome the excitement and the terrible tsunami crashing around Talise beach, then they are around the fishing village. They are really trying to focus on restraint in order not to be carried away with tsunami or not carried away to the center of the sea, although the whole body, hands, and feet are sore and very stiff due to very cold.

In addition, respondents also thought of some sort of possibilities and proper consideration to get out of the location of their shelter in a car, they long waited for a passing vehicle, but all focus with their own interests so They choose to walk and start climbing the road uphill towards the campus more than 5 kilometers, approaching a higher place so as not to suffer the same natural disasters anymore. When the family hears the chaos situation and conditions in the city of Palu, each family immediately fetches them back to the village. This is done in order to restore their physical and mental condition that is starting to weaken and immediately requires more reduced logistics assistance to be consumed.

\section{DISCUSSION}

Due to the harsh conditions that have been encountered in natural disasters, the two students are required to be able to understand, recognize, and manage difficulties into something positive, meaningful, and uplifting the bad experience Moments that strengthen the mental as well as affirm spirituality to be resigned and tenseness about life. Students with high $\mathrm{AQ}$ do not easily give up on difficult conditions and will not easily get stuck in a condition of despair.

It is explained by Garmezy and Michael in Maryanti(2005) suggesting that when faced with the difficulties of life, some individuals fail and are incapable of surviving where they develop problematic patterns of behavior. Others can survive and develop adaptive behaviors, even better when they can get out of trouble and live a healthy life. On this side, the adversity quotient has aspects that can give an overview of the toughness of individuals in the face of obstacles or failures and can predict whether it remains restrained in the face of difficult situations or circumstances. Adversity quotient measures one's ability to face difficulties.
The opinion of Stoltz (2005) states that adversity quotient plays an important role in predicting the extent to which one is able to endure difficulties and how much it can be to overcome the problem. Qualified AQ will make individuals as resilient as personal, and unyielding determination. Individuals who have high adversity quotient will make it immune to helplessness and are not easily trapped in the condition of despair.

Stoltz (2000) argues that in each person has a high level of adversity quotient there is encouragement to continue to grow, the presence of persistence, has good resistance to the pressures of work and high responsibility to continue to develop themselves and will always be motivated to work on their part. As Lasmono Statement (2001) that with high adversity quotient, one will be more and more difficult to face difficulties and able to cope with difficulty precisely so that it can survive with various tough conditions experienced. Adequate Adversity quotient accompanied by a high conviction of his ability will lead to the success of facing stress.

\section{CONCLUSION AND SUGGESTION}

The conclusion in this study was that the description of adversity quotient on two students of PG study Program of PAUD Force 2015 affected by natural disaster tsunami is in the category of climber. It is seen from the four aspects of adversity quotient, i. e. 1) Control (C); 2) Origin-Ownership (O2); 3) Reach (R); and 4) Endurance (E). They tend to demonstrate good control or self-control, as they are able to respond to tsunami events by conducting self-rescue measures appropriately. Origin-Ownership (O2), they realize the difficulties of coming from themselves that make them not pay attention to the conditions surrounding to become more vigilant and disciplined at Maghreb, should be at home. Reach (R) is a difficulty that comes to influence daily activities, but there is a passion and optimism in the future, making them back struggling, steadfast and rigid to re-complete his proposal studies. Last is Endurance (E), able to survive and strive to cope with the ever-continuing difficulties, ranging from those still recovering from trauma, have not focused on proposal completion until finally strengthening themselves by sharing the story with Guardian lecturer and thesis mentor lecturer to obtain positive reinforcement and best support in order to focus on the final goal of becoming a Bachelor of education.

Suggestions related to the practical usability of the results of this study, as follows:

1. Students: In order to train continued AQ, for each aspect that can be improved durability and the power of the competition in order to experience a heavier and difficult situation, has been more capable of self control and emotions are positive and healthier. Similarly, origin-ownership, reach, and endurance. Mental exercises to strengthen AQ become tougher are the best challenge for future readiness. 
2. Mentor Lecturer: should be a good and supportive listener friend in the face of students with poor experience. Need to be given a lot of positive reinforcement and a warm hug when needed. Assisting the completion process of research proposals to the thesis to fulfill their desire to become a bachelor

3. Parents: In order to always provide attentive support and sincere understanding when students experience stress, understand the physical and psychic conditions, the smooth funds needed, and always pray for the smoothness and ease of all matters the student.

Suggestions related to the scientific uses of the results of this study, as follows:

1. Educational institutions: To provide personal recovery therapy facilities or psychosocial mentoring that can be utilized by most students who need their psychic or mental assistance. In addition, provide ease and smoothness for students who are completing their studies.

2. Prospective researchers who wish to take the same theme, can develop or focus on the level of education; Residential environment; Gender of subjects, both male and female, and so on.

3. Interested parties do further research, it is advisable to consider various other factors that can affect the individual's ability to manage adversity quotient, such as emotional intelligence, resilience, academic stress, assertively, and so on.

\section{REFERENCES}

[1] Lasmono, H. K. 2001. Brief overview Adversity Quotient. Anima (Indonesian Psychological Journal), Vol. 17, No. 1, Hal 63 - 68.

[2] Maryanti, P. (2005). Analysis of the acceptance of auditors over dysfunctional audit behavior: A personal characteristics auditor approach. Accounting and Information System management journals. Vol. 3 (2).

[3] Stoltz, P. G. 2005. Adversity Quotient: Turning barriers into opportunities. (Term. T. Hermaya; Ed. Yovita Hardiwati). (Sixth print). Jakarta: PT Grasindo.
[4] Stoltz, P. G. 2000. Adversity Quotient. Turning obstacles into opportunities. Jakarta: Grasindo.

[5] Widyaningrum, J and Rachmawati, 2007. Adversity Intelligence and student learning achievement. Journal of Psychology Projection, Vol. 2, No. 2, Hal $47-56$. 